\title{
WORKLOAD ANALYSIS IN QUALITY CONTROL DEPARTMENT
}

\author{
Pinkie Winandari Budaya ${ }^{1}$, Ahmad Muhsin ${ }^{2}$ \\ Program Studi Teknik Industri \\ Jurusan Teknik Industri Fakultas Teknik Industri \\ Universitas Pembangunan Nasional Veteran Yogyakarta \\ Jl. Babarsari 2 Tambakbayan Yogyakarta 55281 \\ email : pinkiewinandari@gmail.com, ahmad.muhsin@upnyk.ac.id
}

\begin{abstract}
Abstrak
PT XYZ Indonesia adalah perusahaan besar yang bergerak di bidang industri farmasi dan menghasilkan beragam produk seperti obat-obat etikal, nutrisi klinis dan cairan infus, alat-alat kesehatan, dan IV set. PT XYZ memiliki beberapa departemen, salah satunya adalah Departemen Quality Control yang terbagi pula dalam beberapa seksi. Berdasarkan hasil pengamatan, dapat diketahui jika pekerjaan yang dilakukan oleh tenaga kerja Departemen Quality Control Seksi Biologi tergolong tinggi karena dengan job desctiprion yang sudah ditentukan namun hanya dikerjakan oleh tenaga kerja sebanyak 9 orang dan 1 supervisor akan menimbulkan efek kelelahan akibat beban kerja yang berlebihan. Perhitungan beban kerja ini dilakukan dengan metode Workload Analysis. Tahapan yang pertama kali dilakukan adalah mengamati tingkat produktivitas pekerja menggunakan work sampling, menentukan besarnya nilai Performance Rating, Allowance, nilai beban kerja, dan jumlah usulan pekerja. Besarnya beban kerja yang diterima oleh pekerja kemudian digunakan untuk menentukan jumlah pekerja yang seharusnya dipekerjakan agar tidak menerima beban kerja yang berlebih. Hasil perhitungan beban kerja menunjukkan jika 9 orang tenaga kerja memiliki beban kerja yang tinggi karena di atas $100 \%$. Usulan perbaikan yang diberikan untuk mengatasi beban kerja yang tinggi ini adalah dengan menambah jumlah pekerja.
\end{abstract}

Kata kunci: Beban kerja, Workload Analysis, Penambahan jumlah tenaga kerja.

\section{PENDAHULUAN}

Pekerjaan merupakan beban bagi yang menjalani yang dapat berupa beban fisik dan mental. Dari sudut pandang ergonomi, beban kerja yang diterima harus sesuai baik terhadap kemampuan fisik maupun keterbatasan manusia yang menerima beban tersebut. Beban kerja yang melampaui kemampuan kerja tentu akan menimbulkan dampak yang buruk.

PT XYZ Indonesia adalah perusahaan besar yang memiliki ratusan karyawan. Produk yang dihasilkan pun sangat beragam dan diproduksi dalam jumlah banyak. Hal inilah yang menyebabkan begitu banyak pula jumlah produk yang harus diidentifikasi dan dianalisis oleh karyawan Departemen Quality Control. Departemen Quality Control Seksi Biologi sendiri bertanggung jawab atas ratusan dokumen tentang pengujian dan pengendalian kualitas produk dari bagian produksi.

Job description yang dimiliki oleh karyawan serta analisa produk sejumlah 120 sampel setiap harinya (waktu pengantaran sampel tergantung pada Departemen Produksi) tidak seimbang dengan jumlah karyawan yang dipekerjakan pada seksi ini (sembilan orang ditambah satu supervisor). Ketidakseimbangan ini disebabkan karena sampel yang diuji berjumlah lebih banyak daripada karyawan yang bekerja di laboratorium ini. Pekerjaan yang harus dilakukan meliputi pengujian dan penyalinan data secara tertulis (baik manual maupun terkomputerisasi). Beban kerja yang diterima oleh masing-masing karyawan pun menjadi besar antara $140 \%$ sampai dengan 170\%, melampaui batas maksimal yang seharusnya yaitu sebesar $100 \%$. Ketika beban kerja menjadi lebih tinggi dari batas maksimal, 
tentu saja ada dampak buruk yang akan terjadi. Dampak buruk tersebut adalah menurunnya tingkat produktivitas, cepat merasa kelelahan, dan meningkatnya beban psikis yang tidak baik bagi kesehatan karyawan.

\section{LANDASAN TEORI}

Definisi aktivitas produktif menurut Guntar (2008) adalah aktivitas yang sesuai dengan job description yang telah ditentukan dan aktivitas ini dilakukan untuk membuat produk atau jasa. Sementara aktivitas nonproduktif adalah aktivitas yang tidak menghasilkan nilai tambah pada penignkatan kualitas proses dan kecepatan penyelesaian tugas. Tenaga kerja merupakan sumber daya yang penting selain bahan baku, modal, metode, dan mesin. Kualitas dan kuantitas tenaga kerja harus sesuai dengan kebutuhan perusahaan, upaya efektif dan efisien menunjang tercapainya tujuan (Rafian dan Ahmad M, 2017)

Menurut Wignjosoebroto (1995), penentuan waktu longgar (allowance) nantinya dimasukkan ke dalam perhitungan total waktu yang diperlukan suatu posisi untuk menyelesaikan aktivitas-aktivitasnya sangat diperlukan. Pengukuran waktu adalah pekerjaan mengamati pekerja dan mencatat waktu waktu kerjanya baik setiap elemen maupun siklus dengan menggunakan alat alat yang telah disiapkan (Primadi dkk, 2016)

Beban kerja menurut Meshkati dalam Hariyati (2011) dapat didefinisikan sebagai suatu perbedaan antara kapasitas atau kemampuan pekerja dengan tuntutan pekerjaan yang harus dihadapi. Menurut Arif (2008), Workload Analysis (WLA) merupakan salah satu cara yang dapat digunakan untuk menghitung besarnya beban kerja yang diakibatkan oleh aktivitasaktivitas yang dilakukan. Menurut Anggara (2011), beban kerja yang baik sebaiknya mendekati $100 \%$ atau dalam kondisi normal. Perhitungan beban kerja masing-masing elemen dapat diketahui dengan rumus sebagai berikut.
Beban kerja =

$\%$ Produktif $x$ Performance Rating $x$ Total Menit Pengamatan $x(1+$ Allowance $)$ Moekijat dalam Novera (2010) menyatakan bahwa prosedur yang sering digunakan untuk menentukan berapa jumlah tenaga kerja yang diperlukan adalah dengan menganalisis pengalaman. Catatan-catatan tentang hasil pekerjaan dapat menunjukkan volume hasil rata-rata yang dicapai oleh setiap tenaga kerja. Rata-rata tersebut selanjutnya dapat digunakan untuk menaksir kebutuhan tenaga kerja.

Perhitungan jumlah usulan karyawan yang sebaiknya dipekerjakan adalah dengan melakukan pembagian antara besaran beban kerja yang sudah dihitung menggunakan metode WLA dengan suatu taksiran angka di mana hasil dari pembagian tersebut bisa menunjukkan prosentase di bawah 100\%.

\section{METODOLOGI PENELITIAN}

Penelitian ini mengamati tentang beban kerja yang dialami oleh karyawan dengan menggunakan metode Workload Analysis dan menentukan jumlah karyawan optimal yang seharusnya dipekerjakan. Langkahlangkah yang dilakukan dalam melakukan penelitian ini adalah sebagai berikut.

1. Studi Lapangan

Studi lapangan bertujuan untuk mendapatkan informasi mengenai kondisi perusahaan yang sebenarnya.

2. Studi Pustaka

Studi pustaka dilakukan untuk mengetahui dan memahami teori-teori yang berhubungan dengan pemecahan masalah.

3. Rumusan Masalah

Melakukan perumusan masalah berdasarkan studi lapangan dan pustaka yang telah dilakukan.

4. Penentuan Tujuan Penelitian

Tujuan harus ditentukan untuk mengetahui apa saja hal yang ingin dicapai dari dilaksanakannya penelitian ini.

5. Pengumpulan Data 
Data yang dikumpulkan untuk penelitian ini adalah:

a. Data gambaran umum PT XYZ Indonesia

b. Data struktur organisasi

c. Data jumlah pekerja saat ini

d. Data job description tiap pekerjaan

e. Data produktif dan non-produktif karyawan

f. Data performance rating

g. Data allowance

6. Pengolahan Data

Pengolahan data yang dilakukan dalam penelitian ini, yaitu:

a. Menghitung prosentase produktif dan non-produktif dengan metode work sampling

b. Menentukan performance rating dengan metode Westing House System

c. Menentukan allowance

d. Menghitung beban kerja dengan metode Workload Analysis

e. Menentukan jumlah pekerja

7. Analisis dan Kesimpulan

Analisis dan kesimpulan yang dilakukan dalam penelitian ini adalah:

a. Menganalisis besarnya prosentase produkti dan non-produkti masingmasing operator

b. Menganalisis kondisi beban kerja terkait dengan penyebab tingginya beban kerja

c. Analisis terkait dengan jumlah pekerja di mana akan membandingkan banyaknya pekerja yang ada saat ini dengan banyaknya pekerja berdasarkan beban kerjanya

\section{HASIL DAN PEMBAHASAN}

Aktivitas Produktif dan Non-produktif Karyawan Departemen Quality Control Seksi Biologi. Data kegiatan produktif dan nonproduktif ini digunakan untuk perhitungan beban kerja. Beban kerja tersebut kemudian dapat digunakan untuk mengidentifikasi apakah beban kerja yang diterima melebihi batas maksimal (lebih dari 100\%) atau tidak.
Ketika beban kerja yang diterima lebih dari $100 \%$, maka usulan yang disarankan adalah penambahan karyawan.

Kegiatan produktif dan non-produktif dapat dilakukan dengan membandingkan job description yang dimiliki masing-masing pekerja dengan kegiatan yang sebenarnya mereka lakukan pada saat pengamatan. Data jumlah kegiatan produktif dan non-produktif yang dilakukan oleh pekerja selama pengamatan ditunjukkan pada tabel-tabel berikut.

Tabel 1 Data kegiatan produktif/ nonproduktif Hasan Abdul Nazar

\begin{tabular}{|c|c|c|c|}
\hline No. & $\begin{array}{c}\text { Hari } \\
\text { Ke- }\end{array}$ & $\begin{array}{c}\text { Kegiatan } \\
\text { Produktif }\end{array}$ & $\begin{array}{c}\text { Kegiatan Non- } \\
\text { Produktif }\end{array}$ \\
\hline 1 & 1 & 27 & 3 \\
\hline 2 & 2 & 28 & 2 \\
\hline 3 & 3 & 29 & 1 \\
\hline 4 & 4 & 29 & 1 \\
\hline 5 & 5 & 28 & 2 \\
\hline
\end{tabular}

Tabel 2 Data kegiatan produktif/ nonproduktif Mafruhatun Ni'mah

\begin{tabular}{|c|c|c|c|}
\hline No. & $\begin{array}{c}\text { Hari } \\
\text { Ke- }\end{array}$ & $\begin{array}{c}\text { Kegiatan } \\
\text { Produktif }\end{array}$ & $\begin{array}{c}\text { Kegiatan Non- } \\
\text { Produktif }\end{array}$ \\
\hline 1 & 1 & 28 & 2 \\
\hline 2 & 2 & 30 & 0 \\
\hline 3 & 3 & 30 & 0 \\
\hline 4 & 4 & 28 & 2 \\
\hline 5 & 5 & 29 & 1 \\
\hline
\end{tabular}

Tabel 3 Data kegiatan produktif/ nonproduktif Alfian Dwi Kurniawan

\begin{tabular}{|c|c|c|c|}
\hline No. & $\begin{array}{c}\text { Hari } \\
\text { Ke- }\end{array}$ & $\begin{array}{c}\text { Kegiatan } \\
\text { Produktif }\end{array}$ & $\begin{array}{c}\text { Kegiatan Non- } \\
\text { Produktif }\end{array}$ \\
\hline 1 & 1 & 27 & 3 \\
\hline 2 & 2 & 29 & 1 \\
\hline 3 & 3 & 30 & 0 \\
\hline 4 & 4 & 28 & 2 \\
\hline 5 & 5 & 29 & 1 \\
\hline
\end{tabular}

Tabel 4 Data kegiatan produktif/ nonproduktif Deddy Prasetyo

\begin{tabular}{|c|c|c|c|}
\hline No. & $\begin{array}{c}\text { Hari } \\
\text { Ke- }\end{array}$ & $\begin{array}{c}\text { Kegiatan } \\
\text { Produktif }\end{array}$ & $\begin{array}{c}\text { Kegiatan Non- } \\
\text { Produktif }\end{array}$ \\
\hline 1 & 1 & 29 & 1 \\
\hline 2 & 2 & 30 & 0 \\
\hline 3 & 3 & 30 & 0 \\
\hline
\end{tabular}




\begin{tabular}{|l|l|l|l|}
\hline 4 & 4 & 28 & 2 \\
\hline 5 & 5 & 29 & 1 \\
\hline
\end{tabular}

Tabel 5 Data kegiatan produktif/ nonproduktif Tatik Suharyati

\begin{tabular}{|c|c|c|c|}
\hline No. & $\begin{array}{c}\text { Hari } \\
\text { Ke- }\end{array}$ & $\begin{array}{c}\text { Kegiatan } \\
\text { Produktif }\end{array}$ & $\begin{array}{c}\text { Kegiatan Non- } \\
\text { Produktif }\end{array}$ \\
\hline 1 & 1 & 30 & 0 \\
\hline 2 & 2 & 30 & 0 \\
\hline 3 & 3 & 26 & 4 \\
\hline 4 & 4 & 30 & 0 \\
\hline 5 & 5 & 30 & 0 \\
\hline
\end{tabular}

Tabel 6 Data kegiatan produktif/ nonproduktif Suci Rahmawati

\begin{tabular}{|c|c|c|c|}
\hline No. & $\begin{array}{c}\text { Hari } \\
\text { Ke- }\end{array}$ & $\begin{array}{c}\text { Kegiatan } \\
\text { Produktif }\end{array}$ & $\begin{array}{c}\text { Kegiatan Non- } \\
\text { Produktif }\end{array}$ \\
\hline 1 & 1 & 29 & 1 \\
\hline 2 & 2 & 28 & 2 \\
\hline 3 & 3 & 28 & 2 \\
\hline 4 & 4 & 30 & 0 \\
\hline 5 & 5 & 28 & 2 \\
\hline
\end{tabular}

Tabel 7 Data kegiatan produktif/ nonproduktif Yayang Wijaya

\begin{tabular}{|c|c|c|c|}
\hline No. & $\begin{array}{c}\text { Hari } \\
\text { Ke- }\end{array}$ & $\begin{array}{c}\text { Kegiatan } \\
\text { Produktif }\end{array}$ & $\begin{array}{c}\text { Kegiatan Non- } \\
\text { Produktif }\end{array}$ \\
\hline 1 & 1 & 30 & 0 \\
\hline 2 & 2 & 29 & 1 \\
\hline 3 & 3 & 29 & 1 \\
\hline 4 & 4 & 30 & 0 \\
\hline 5 & 5 & 27 & 3 \\
\hline
\end{tabular}

Tabel 8 Data kegiatan produktif/ nonproduktif M. Isa Ansori

\begin{tabular}{|c|c|c|c|}
\hline No. & $\begin{array}{c}\text { Hari } \\
\text { Ke- }\end{array}$ & $\begin{array}{c}\text { Kegiatan } \\
\text { Produktif }\end{array}$ & $\begin{array}{c}\text { Kegiatan Non- } \\
\text { Produktif }\end{array}$ \\
\hline 1 & 1 & 28 & 2 \\
\hline 2 & 2 & 28 & 2 \\
\hline 3 & 3 & 28 & 2 \\
\hline 4 & 4 & 28 & 2 \\
\hline 5 & 5 & 28 & 2 \\
\hline
\end{tabular}

Tabel 9 Data kegiatan produktif/ nonproduktif Sunarko

\begin{tabular}{|c|c|c|c|}
\hline No. & $\begin{array}{c}\text { Hari } \\
\text { Ke- }\end{array}$ & $\begin{array}{c}\text { Kegiatan } \\
\text { Produktif }\end{array}$ & $\begin{array}{c}\text { Kegiatan } \\
\text { Non- } \\
\text { Produktif }\end{array}$ \\
\hline 1 & 1 & 29 & 1 \\
\hline 2 & 2 & 29 & 1 \\
\hline
\end{tabular}

\begin{tabular}{|l|l|l|l|}
\hline 3 & 3 & 29 & 1 \\
\hline 4 & 4 & 29 & 1 \\
\hline 5 & 5 & 29 & 1 \\
\hline
\end{tabular}

Uji kecukupan data dilakukan untuk mengetahui banyaknya pengamatan yang harus dilakukan dalam work sampling. Untuk menghitung banyaknya pengukuran yang diperlukan untuk tingkat ketelitian 5\% dan tingkat keyakinan 95\% adalah sebagai berikut.

$$
\mathrm{N}^{\prime}=\frac{k^{2}(1-\bar{p})}{s^{2} \cdot \bar{p}}
$$

Hasil perhitungan uji kecukupan data ditampilkan pada Tabel 10 berikut.

Tabel 10 Hasil uji kecukupan data

\begin{tabular}{|c|c|c|c|}
\hline Nama & $\mathrm{N}$ & $\mathrm{N}^{\prime}$ & Keterangan \\
\hline Hasan AN & 150 & 102 & $\mathrm{~N}>\mathrm{N}^{\prime}$, data cukup \\
\hline $\begin{array}{l}\text { Mafruhatun } \\
\mathrm{N}\end{array}$ & 150 & 56 & $\mathrm{~N}>\mathrm{N}^{\prime}$, data cukup \\
\hline $\begin{array}{l}\text { Alfian Dwi } \\
\text { Kurniawan }\end{array}$ & 150 & 91 & $\mathrm{~N}>\mathrm{N}^{\prime}$, data cukup \\
\hline Deddy P. & 150 & 44 & $\mathrm{~N}>\mathrm{N}^{\prime}$, data cukup \\
\hline $\begin{array}{l}\text { Suci } \\
\text { Rahmawati }\end{array}$ & 150 & 79 & $\mathrm{~N}>\mathrm{N}^{\prime}$, data cukup \\
\hline Tatik S. & 150 & 44 & $\mathrm{~N}>\mathrm{N}^{\prime}$, data cukup \\
\hline $\begin{array}{l}\text { Yayang } \\
\text { Wijaya }\end{array}$ & 180 & 65 & $\mathrm{~N}>\mathrm{N}^{\prime}$, data cukup \\
\hline Sunarko & 180 & 65 & $\mathrm{~N}>\mathrm{N}^{\prime}$, data cukup \\
\hline M. Isa & 180 & 65 & $\mathrm{~N}>\mathrm{N}^{\prime}$, data cukup \\
\hline
\end{tabular}

Uji keseragaman data dilakukan untuk mengetahui apakah data yang didapat telah seragam dan tidak melebihi batas kontrol atas (BKA) dan batas kontrol bawah (BKB) yang telah ditentukan. Rumus dari batas kontrol atas dan batas kontrol bawah adalah sebagai berikut.

$$
\begin{aligned}
& \mathrm{BKA}=\overline{\mathrm{p}}+k \sqrt{\frac{\overline{\bar{p}(1-\overline{\mathrm{p}})}}{n}} \\
& \mathrm{BKB}=\overline{\mathrm{p}}-k \sqrt{\frac{\overline{\mathrm{p}}(1-\overline{\mathrm{p}})}{n}}
\end{aligned}
$$


Hasil perhitungan uji keseragaman data ditampilkan pada Tabel 11 berikut.

Tabel 11 Hasil uji keseragaman data

\begin{tabular}{|l|c|c|c|l|}
\hline \multicolumn{1}{|c|}{ Nama } & $\begin{array}{c}\% \\
\text { Produktif }\end{array}$ & BKA & BKB & Ket. \\
\hline $\begin{array}{l}\text { Hasan } \\
\text { AN }\end{array}$ & 94 & 1,157 & 0,723 & $\begin{array}{l}\text { Data } \\
\text { seragam }\end{array}$ \\
\hline $\begin{array}{l}\text { M. } \\
\text { Ni'mah }\end{array}$ & 96,6 & 1,131 & 0,801 & $\begin{array}{l}\text { Data } \\
\text { seragam }\end{array}$ \\
\hline $\begin{array}{l}\text { Alfian } \\
\text { DK }\end{array}$ & 94,6 & 1,152 & 0,740 & $\begin{array}{l}\text { Data } \\
\text { seragam }\end{array}$ \\
\hline $\begin{array}{l}\text { Deddy } \\
\text { P. }\end{array}$ & 97,3 & 1,114 & 0,832 & $\begin{array}{l}\text { Data } \\
\text { seragam }\end{array}$ \\
\hline $\begin{array}{l}\text { Suci R. } \\
\text { Tatik S. }\end{array}$ & 95,3 & 1,111 & 0,795 & $\begin{array}{l}\text { Data } \\
\text { seragam }\end{array}$ \\
\hline $\begin{array}{l}\text { Yayang } \\
\text { Wijaya } \\
\text { (pagi) }\end{array}$ & 96,1 & 1,119 & 0,803 & $\begin{array}{l}\text { Data } \\
\text { seragam } \\
\text { seragam }\end{array}$ \\
\hline $\begin{array}{l}\text { Sunarko } \\
\text { (pagi) }\end{array}$ & 96,1 & 1,119 & 0,803 & $\begin{array}{l}\text { Data } \\
\text { seragam }\end{array}$ \\
\hline $\begin{array}{l}\text { M. Isa } \\
\text { (pagi) }\end{array}$ & 96,1 & 1,119 & 0,803 & $\begin{array}{l}\text { Data } \\
\text { seragam }\end{array}$ \\
\hline $\begin{array}{l}\text { Yayang } \\
\text { W. } \\
\text { (siang) }\end{array}$ & 96,7 & 1,125 & 0,809 & $\begin{array}{l}\text { Data } \\
\text { seragam }\end{array}$ \\
\hline $\begin{array}{l}\text { Sunarko } \\
\text { (siang) }\end{array}$ & 96,7 & 1,125 & 0,809 & $\begin{array}{l}\text { Data } \\
\text { seragam }\end{array}$ \\
\hline $\begin{array}{l}\text { M. Isa } \\
\text { (siang) }\end{array}$ & 96,7 & 1,125 & 0,809 & $\begin{array}{l}\text { Data } \\
\text { seragam }\end{array}$ \\
\hline
\end{tabular}

Perhitungan akan rating ini diharapkan bisa "menormalkan" kembali waktu kerja yang telah diukur. Data faktor penyesuaian yang digunakan pada penelitian ini adalah menggunakan cara Westinghouse. Westinghouse mengarahkan penilaian pada empat faktor yang dianggap menentukan kewajaran atau ketidakwajaran dalam bekerja yaitu keterampilan, usaha, kondisi kerja, dan konsistensi. Hasil perhitungan rating factor dan allowance dirangkum ditampilkan pada Tabel 12 berikut.

Tabel 12 Rangkuman rating factor dan allowance

\begin{tabular}{|c|c|c|}
\hline Nama & RF & All (\%) \\
\hline Hasan Abdul & 1,386 & 1670 \\
\hline
\end{tabular}

\begin{tabular}{|l|c|c|}
\hline Nazar & & \\
\hline $\begin{array}{l}\text { Mafruhatun } \\
\text { Ni'mah }\end{array}$ & 1,368 & 14,25 \\
\hline $\begin{array}{l}\text { Alfian Dwi } \\
\text { Kurniawan }\end{array}$ & 1,644 & 17,90 \\
\hline Deddy P. & 1,644 & 17,90 \\
\hline Suci Rahmawati & 1,368 & 18,00 \\
\hline Tatik S. & 1,368 & 18,00 \\
\hline Yayang Wijaya & 1,644 & 17,90 \\
\hline Sunarko & 1,644 & 17,90 \\
\hline M. Isa & 1,644 & 17,90 \\
\hline
\end{tabular}

Hasil dari perhitungan beban kerja dan jumlah karyawan optimal yang diusulkan ditampilkan pada Tabel 13 dan Tabel 14 berikut.

Tabel 13 Rangkuman beban kerja

\begin{tabular}{|c|c|}
\hline Nama & Beban Kerja (\%) \\
\hline Hasan Abdul Nazar & 149,7 \\
\hline Mafruhatun Ni'mah & 150,9 \\
\hline $\begin{array}{c}\text { Alfian Dwi } \\
\text { Kurniawan }\end{array}$ & 183,4 \\
\hline Deddy P. & 188,6 \\
\hline Suci Rahmawati & 153,8 \\
\hline Tatik S. & 157,1 \\
\hline $\begin{array}{c}\text { Yayang Wijaya } \\
\text { (pagi) }\end{array}$ & 155,2 \\
\hline Sunarko (pagi) & 155,2 \\
\hline M. Isa (pagi) & 155,2 \\
\hline $\begin{array}{c}\text { Yayang Wijaya } \\
\text { (siang) }\end{array}$ & 187,4 \\
\hline Sunarko (siang) & 187,4 \\
\hline M. Isa (siang) & 187,4 \\
\hline
\end{tabular}

Tabel 14 Jumlah optimal karyawan usulan peneliti

\begin{tabular}{|c|c|}
\hline Nama & $\begin{array}{c}\text { Jumlah Usulan } \\
\text { Tambahan } \\
\text { Tenaga Kerja }\end{array}$ \\
\hline Hasan AN & \multirow{6}{*}{ 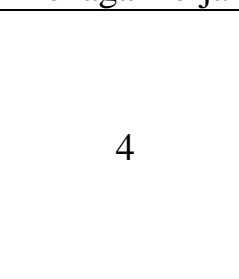 } \\
\hline M. Ni'mah & \\
\hline Alfian DK & \\
\hline Deddy P. & \\
\hline Suci R & \\
\hline Tatik S. & \\
\hline Yayang W. (pagi) & \multirow{6}{*}{3} \\
\hline Sunarko (pagi) & \\
\hline M. Isa (pagi) & \\
\hline Yayang W. (siang) & \\
\hline Sunarko (siang) & \\
\hline M. Isa (siang) & \\
\hline
\end{tabular}




\section{KESIMPULAN}

Kesimpulan dari penelitian ini adalah untuk mengetahui nilai dan menganalisis beban kerja yang dialami oleh masingmasing pekerja tersebut. Beban kerja yang dialami oleh karyawan pada Departemen Quality Control Seksi Biologi tergolong pada beban kerja tinggi karena setelah dilakukan pengamatan dan perhitungan ternyata semua karyawan menerima beban kerja di atas 100 $\%$, di mana batas maksimal beban kerja yang seharusnya diterima adalah $100 \%$. Penyebab tingginya beban kerja ini disebabkan karena jumlah pekerjaan yang sangat banyak namun tidak diimbangi dengan jumlah karyawan yang sepadan sehingga setiap karyawan pun memikul job description yang sangat padat dan beragam.

\section{DAFTAR PUSTAKA}

Ariandi, F.D. 2017. "Laporan Praktik Lapangan Mempelajari Teknologi Produksi Infus dan Penggudangan pada PT Otsuka Indonesia”. Fakultas Teknologi Pertanian. Institut Pertanian Bogor. Bogor.

Aristi, N. dan Hafiar, H. 2014, "Analisis Beban Kerja Tenaga Pendidik dan Kependidikan di Fakultas $Y$ Universitas X'. Jurnal Kajian Komunikasi Volume 2, No. 1, pp 54.

Astianto, A. dan Suprihhadi, H. 2014, "Pengaruh Stres Kerja dan Beban Kerja Terhadap Kinerja Karyawan PDAM Surabaya". Jurnal Ilmu \& Riset Manajemen Vol. 3 No. 7, pp 1 8.

Daud, N.Z. 2016. "Laporan Praktek Kerja Profesi Apoteker Mahasiswa Fakultas Universitas Surabaya Bidang Minat Utama Farmasi Industri Angkatan 51 di PT Otsuka Indonesia”. Fakultas Farmasi. Universitas Surabaya. Surabaya.
Hutapea, J.J. 2014. "Praktik Kerja Profesi PT Otsuka Indonesia". Fakultas Farmasi. Universitas Airlangga. Surabaya.

Prabowo, A., dkk. 2017, "Analisa Beban Kerja dan Penentuan Tenaga Kerja Optimal dengan Pendekatan Work Load Analysis (WLA)". Jurnal Teknik Industri Vol. 5 No. 1, pp 3.

Putri, E.R. 2015. "Peramalan Jumlah Permintaan dan Analisis Inventory Turn Over Infus Otsu-D5 dan OtsuNS di PT Otsuka Indonesia”. Fakultas Teknik. Universitas Brawijaya.

Putri, R.K. 2012. "Pengendalian Kualitas Statistik P-Chart dan Analisis Kemampuan Proses Binomial pada Produk Infus Plabottle di PT Otsuka Indonesia". Jurusan Matematika FMIPA. Universitas Negeri Malang. Malang.

Putri, R.N. 2017. "Analisis Pengendalian Kualitas Produk Otsu-NS $500 \mathrm{ML}$ Menggunakan Peta Kendali P". Fakultas Teknik Industri. Universitas Pembangunan Nasional "Veteran" Yogyakarta. Yogyakarta.

Primadi, Shelfian Dumas, Dyah Rachmawati .L, Ahmad Muhsin, 2016, Usulan Perbaikan Tingkat Pencahayaan Pada Ruang Produksi Guna Peningkatan Output Produk Pekerja Dengan Pendekatan Teknik Tata Cara Kerja, Jurnal OPSI, Vol 9 No.1 Juni 2016, hlm 59 - 68, dapat diakses di http://eprints.upnyk.ac.id/1137/

Rafian, Ade Muhammad dan Ahmad Muhsin, 2017, Analisis Beban Kerja Mekanik Pada Departemen Plant dengan Metode Work Sampling, Jurnal OPSI, Vol 10 No 1 Juni 2017, hlm 35-42, dapat diakses di http://jurnal.upnyk.ac.id/index.php/op si/article/download/2165/1905

Rinawati, D.I. dkk. 2012, "Penentuan Waktu Stanaar dan Jumlah Tenaga Kerja Optimal pada Produksi Batik Cap 
(Studi Kasus: IKM Batik Saud Effendy, Laweyan)". J@TI Undip Vol VII No.3, pp 145.

Sutalaksana, I.Z., dkk. 1979, Teknik Tata

Cara Kerja. Bandung: Jurusan Teknik Industri Institut Teknologi Bandung.

Wibowo, K.D. dkk. 2004, "Analisa Produktivitas Pekerja dengan Metode Work Sampling: Studi Kasus pada Proyek $X$ dan $Y$ '. Civil Engineering Dimension, Vol. 6, No. 2, pp 74. 